\title{
Determinants of Talent Retention in Textile and Garment Companies in Binh Duong Province*
}

\author{
Thanh-Lam NGUYEN ${ }^{1}$
}

Received: March 29, 2020 Revised: April 11, 2020 Accepted: May 01, 2020

\begin{abstract}
This study investigates determinants of talent retention in textile and garment companies located in Vietnam's Binh Duong province to propose feasible actions for their sustainable development in the current context of competition on the labor market. This study uses selfcompleted questionnaires to collect data which are then analysed with statistical methods including scale reliability, exploratory factor analysis, and multiple linear regression. Specifically, results from an official survey of 129 people who are regarded as talents in related companies show that there are ten determinants, ranked in descending order of their importance, including: working environment; training and promotion opportunities; salary and benefits; personal loyalty; relationship with colleagues; nature of work; organizational recognition; type of ownership; relationship with superiors; and working experience. Moreover, it is also found that foreign companies are better in retaining their talents than private domestic ones. These findings suggest that, depending on their available resources, organizations need to focus on some of these factors to improve their talent retention; among them, it is critical to provide creative space or create conductive working environment by providing talents with proper tools and equipment for them to feel excited with their work and get things done in an optimal, efficient and effective manner.
\end{abstract}

Keywords : Binh Duong Textile \& Garment, Determinants, Talent Retention, Vietnam.

JEL Classification Code: M12, M54, B23, J50

\section{Introduction}

The modern economy needs high quality human resources (HRs), especially those regarded as "talents". As the number of skilled HRs is limited, such strong needs further emphasize their importance (Menefee \& Murphy, 2004). Organizations tend to suffer a lot if they lose their talents. Hence, many organizations offer attractive incentives to retain them and lure those away from their competitors, resulting in the popular "leap frog" phenomenon (Lathitha, 2012).

*Special thanks to Lac Hong University for effectively providing necessary resources and policies to improve the research capacity of its faculties.

${ }^{1}$ First Author and Corresponding Author. Head, Office of International Affairs, Lac Hong University, Vietnam [Postal Address: 10 Huynh Van Nghe, Buu Long, Bien Hoa, Dong Nai, 810000, Vietnam] Email: lamnt@Ihu.edu.vn; green4rest.vn@gmail.com

(c) Copyright: The Author(s)

This is an Open Access article distributed under the terms of the Creative Commons Attribution Non-Commercial License (http://Creativecommons.org/licenses/by-nc/4.0/) which permits unrestricted noncommercial use, distribution, and reproduction in any medium, provided the original work is properly cited.
Thus, how to retain talents becomes the everlasting request for organization leaders to prudently consider in developing related policies (Botha, 2011). Mohammed (2015) claims that organizations need to have distinct policies to retain their talents to ensure their own competitive advantage through high quality HRs because the HRs are considered valuable, rare, imbalanced and irreplaceable (Bartel, 2004; Becker \& Huselid, 2006; Rola \& Thomas, 2013). They are appreciated as "human capital" (Chulanova, Satybaldin \& Koshanov, 2019; Chulanova \& Ussenova, 2015).

And the global economic integration leads to an aggressive race on marketplaces. In such races, organizations will have their advantages if they can provide good products and services at a rational cost; i.e., they must improve their efficiency and labor productivity. As modern talents are highly skilled, qualified and experienced, they are always welcomed by organizations to control their modern machineries and technologies (Birt, Wallis \& Winternitz, 2004). Basically, it is found that retaining a current talent is much more difficult than recruiting a new one (Tarique \& Schuler, 2010; Schuler, Jackson \& Tarique, 2011; Scullion, Collings \& Caligiuri, 2011). According to Ng'ethe, Iravo 
and Namusonge (2012), good management of talent will help organizations to generally stabilize their business, operate better than others, and create a decent basis for their sustainable development because talent management helps organizations secure the right people with the right skills at the right time to engage in strategically important decisions that ensure success and improve their organizational capacity (Mohammed, 2015).

Practically, several professional organizations report that many provinces and cities in Vietnam are deficient in qualified HR for textile and garment companies; consequently, there is an strong competition to attract and retain talents in the industry, resulting in a high turnover rate in this sector. Specifically, in Binh Duong, the phenomenon of leap frogging in this sector happens not only with regular workers, but also with management personnel. In order to help textile and garment companies in Binh Duong province to effectively improve talent retention, this research aims at identifying factors affecting talent retention and propose managerial implications to deal with the problem.

\section{Materials and Methods}

\subsection{Definition of "Talent"}

In a same field, talents are usually more proficient than others (Gagné, 2000) because they possess exceptional capability and attainment in a dedicated field of specialty and prove to be exceedingly effective in almost every circumstances (Williams, 2000; Axelrod et al., 2001). Similarly, Michaels et al. (2002) claimed that talents have "outstanding ability" in terms of inward competences, skills, knowledge, experience, intellect, verdict, and suitable insolences to effectively deal with allotted tasks.

Meanwhile, Thorne and Pellent (2007) defined a talent as a person who has a superior strength and is capable of performing better than others for the same effort. So, talents have high professional credentials and ethics as well as good self-esteem. They usually have smart and logical working approaches, suggest good resolutions for their leaders, propose pioneering ideas to produce a turning point or timely resolve difficulties that happened in the business activities (Quynh et al., 2016; Nguyen et al., 2019). As such, the term "talent" proposed by Thorne and Pellent (2007) is found appropriate and employed in this study.

\subsection{Talent Retention}

Hassan, Hassan, Khan and Naseem (2011) claimed that retaining a talent is to keep a person who has made contributions or has a potential to contribute significantly to the organization's performance and development. Till now, there is no commonly-accepted definition of talent retention yet, but we can reckon that it is all about how to make talents happy to stay and serve the organization with their extreme wishes. Though it is quite simple to know the concept, it is still very challenging to retain them and/or attract other talents and skilled workforces because organizations must have attractive and competitive policies (Singh \& Dixit, 2011). If dissatisfied with current organization, a talent tends to switch to another organization because they are always appreciated on the labor market. Consequently, retaining a talent is far more important than attracting new one.

\subsection{Factors that Affect the Retention of Talent}

Benjamin and Dunford (2010) believed that rewards based on stock ownership can be used to attract and retain talents while Matkeri (2011) claimed that wage incentives and performance bonuses are easier approaches. Talents want enduring association with their organizations, but if they are unhappy with issues such as wages and income, the balance between life and work, career progress and personal skills, they tend to simply shift jobs (Slavich, 2011).

Tansley (2011) believes that a virtuous and reasonable milieu is required for talent retention. It is also significant for organizations to: (1) provide crucial work settings for decent staffs to perform well their tasks and have a chance for advancement in their careers; (2) offer satisfactory paybacks and welfares to boost their performance; (3) eradicate negative influences such as stagnant staffs, ineffective or envy workers, etc.; and (4) provide suitable conditions for talents to feel that their existence is indispensable for their organizations. Talent retention is affected by: organizational culture, communication, strategy, salary and benefits, flexible scheduling and opportunity to perfect themselves (Logan, 2000). Meanwhile, Masibigiri and Nienaber (2011) pointed that talent retention is enticed by several factors, including their commitment, engagement, communication environment, leadership styles and intrapersonal contacts, and HR management policies.

On the other hand, talent tends to be more involved if they are allowed to participate in decision-making process because it makes them feel empowered, respected and important in contributing their minds to the development of their organization (Moorhead \& Griffin, 2004).

In addition, interesting nature of work (Hossain \& Hossain, 2012), and work motivation (Chowdhury, 2007; Reena, Jalilvand, Sharif \& Khanzadeh, 2009) are important determinants in helping workers to complete their missions. Safiullah (2015) found the following: job security, relationships with superiors, rational valuation based on performance, fidelity, supportive spirit among colleagues, working atmosphere, promotion opportunities, participation in vital issues, and proper assignments. Accordingly, talent retention is also affected by personal 
faithfulness (Yen, Hu, Hsu \& Li, 2016). Guillon and Cezanne (2014) pointed that faithful employees tend to be contented with their jobs and complete their assigned tasks with high efficiency. The loyalty closely relates to the way they are treated (Tulsi \& Ji, 2020). Specifically, if employees feel that they are fairly treated, they rarely switch jobs (Guillon \& Cezanne, 2014; Ibrahim \& Al Falasi, 2014; Iqbal et al.; 2015; Martensen \& Grønholdt, 2015). And the loyalty mentioned in this study is considered in two respects: (1) the nature of human characteristics; and (2) attachment to the organization.

\subsection{Research Method}

From the above studies, in addition to personal and organizational characteristics, there are eight determinants used in this study: (1) salary and benefits; (2) nature of work; (3) training and promotion opportunities; (4) recognition by the organization; (5) relationship with superiors; (6) relationship with colleagues; (7) working environment; and, (8) personal loyalty (see Table 1). Therefore, our research model is formulated as in Figure 1.

\subsubsection{Data Collection}

This study uses a questionnaire and proceeds through two main steps: (1) pilot research and (2) formal study. Specifically, the pilot research was conducted with five participants who were group leaders from a textile company located in VSIP II Industrial Park to examine the clarity and uniqueness of the survey questions as well as eliciting their comments to refine our questionnaire before conducting the official survey. The content of the observed variables is shown in Table 2.

\subsubsection{Data Analysis}

This study uses a number of data analysis methods, which are widely used in socio-economic studies such as: scale reliability analysis, exploratory factor analysis (EFA), and linear regression analysis. In statistics, the reliability of a scale is evaluated by Cronbach's Alpha coefficient $(\alpha)$ and item-total correlation coefficient for each factor constituting the scale. In the socio-economic field, many researchers agree that when Cronbach's Alpha is 0.8 or nearly 1.0 , the scale is considered good, i.e., the consistency of the items in the scale is high; from 0.7 to nearly 0.8 , the scale is rated as good, and 0.6 or more is acceptable (Nunnally \& Bernstein, 1994; Peterson, 1994; Slater, 1995). In addition, the itemtotal correlation of a variable must be greater than 0.3 to be considered satisfactory (Nunnally \& Bernstein, 1994).

After reliability analysis, satisfied scales will be further analysed with exploratory factor analysis (EFA). In the
EFA analysis, three parameters to be carefully investigated include: (1) the number of factors extracted; (2) factor loading; and (3) total variance extracted. If the EFA analysis results show that these three conditions are satisfactory, it is concluded that the EFA model is appropriate (Hair, Black, Babin, Anderson\& Tatham, 2010); i.e. using the EFA analysis approach in the study is appropriate.

A multivariate regression analysis is also used to analyze the relationship between a dependent variable and multiple independent variables to predict the degree of dependent variable (with limited accuracy) when the

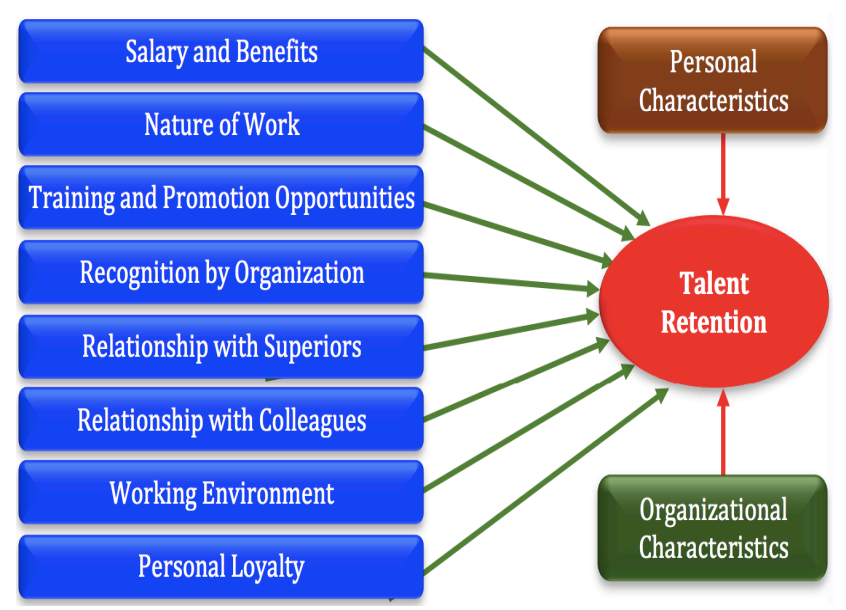

Figure 1: Proposed research model

Table 1: Investigated hypotheses

\begin{tabular}{|l|l|c|}
\hline \multicolumn{2}{|c|}{ Hypotheses } & Expectation \\
\hline H1 & $\begin{array}{l}\text { Salary and benefits have positive } \\
\text { impacts on talent retention. }\end{array}$ & + \\
\hline H2 & $\begin{array}{l}\text { Nature of work has positive impacts } \\
\text { on talent retention. }\end{array}$ & + \\
\hline H3 & $\begin{array}{l}\text { Training and promotion } \\
\text { opportunities have positive impacts } \\
\text { on talent retention. }\end{array}$ & + \\
\hline H4 & $\begin{array}{l}\text { Recognition by organization has } \\
\text { positive impacts on talent retention. }\end{array}$ & + \\
\hline H5 & $\begin{array}{l}\text { Relationships with superiors have } \\
\text { positive impacts on talent retention. }\end{array}$ & + \\
\hline H6 & $\begin{array}{l}\text { Relationships with colleagues have } \\
\text { positive impacts on talent retention. }\end{array}$ & + \\
\hline H7 & $\begin{array}{l}\text { Working environment has positive } \\
\text { impacts on talent retention. }\end{array}$ & + \\
\hline H8 & $\begin{array}{l}\text { Personal loyalty has positive } \\
\text { impacts on talent retention. }\end{array}$ \\
\hline
\end{tabular}


Table 2: Coding of observed variables

\begin{tabular}{|c|c|c|}
\hline Factor & Observed variable & Code \\
\hline \multirow{7}{*}{$\begin{array}{l}\text { Salary and Benefits } \\
\text { (LC) }\end{array}$} & You are paid based on your performance. & LC1 \\
\hline & Your current salary is enough for your family expenditures. & LC2 \\
\hline & The salary is scientifically calculated. & LC3 \\
\hline & You will have higher salary for better performance. & LC4 \\
\hline & There is a favourable treatment policy for talents. & LC5 \\
\hline & There is an appealing reward policy. & LC6 \\
\hline & Relevant insurances for employees are fully implemented. & LC7 \\
\hline \multirow{4}{*}{$\begin{array}{l}\text { Nature of Work } \\
(B C)\end{array}$} & You are clear with all job requirements and responsibilities. & $\mathrm{BC} 1$ \\
\hline & Your work matches your capacity and interest. & $\mathrm{BC} 2$ \\
\hline & Your work needs your proactiveness and creativity. & $\mathrm{BC} 3$ \\
\hline & Your work brings happiness to you. & $\mathrm{BC} 4$ \\
\hline \multirow{4}{*}{$\begin{array}{l}\text { Training and } \\
\text { Promotion } \\
\text { Opportunities (DT) }\end{array}$} & You are encouraged to have higher education and training. & DT1 \\
\hline & There is an explicit policy for promoting talents. & DT2 \\
\hline & Policies in training and promotion are publicly circulated within the organization. & DT3 \\
\hline & Capable employees are always considered for promotion. & DT4 \\
\hline \multirow{5}{*}{$\begin{array}{l}\text { Recognition by } \\
\text { Organization } \\
(\mathrm{CN})\end{array}$} & Your good performance is always appreciated. & CN1 \\
\hline & Employees are complimented and encouraged. & CN2 \\
\hline & Your opinions and reflections are welcomed. & CN3 \\
\hline & Employees' opinions are satisfactorily considered. & CN4 \\
\hline & Productivity is one of the key criteria for promotion. & CN5 \\
\hline \multirow{4}{*}{$\begin{array}{l}\text { Relationship with } \\
\text { Superiors } \\
\text { (CT) }\end{array}$} & Your superiors provide good conditions to favour your work. & CT1 \\
\hline & Your superiors are friendly and condescending. & CT2 \\
\hline & Your superiors treat you fairly and unbiased. & CT3 \\
\hline & Your superiors always try to listen and understand you. & CT4 \\
\hline \multirow{5}{*}{$\begin{array}{l}\text { Relationship with } \\
\text { Colleagues } \\
(\mathrm{DN})\end{array}$} & Your colleagues are always willing to help each other. & DN1 \\
\hline & Your colleagues love you. & DN2 \\
\hline & There is no conflict between you and your colleagues. & DN3 \\
\hline & Your colleagues always encourage each other. & DN4 \\
\hline & You feel connected with your colleagues. & DN5 \\
\hline \multirow{6}{*}{$\begin{array}{l}\text { Working Environment } \\
\text { (MT) }\end{array}$} & You are equipped with necessary tools and facilities. & MT1 \\
\hline & Tools and equipment are in good conditions. & MT2 \\
\hline & Lights and air-conditioners well fit for your work. & MT3 \\
\hline & Working spaces are kept clean. & MT4 \\
\hline & You feel safe in your work-places. & MT5 \\
\hline & You feel comfortable in your work-places. & MT6 \\
\hline \multirow{3}{*}{$\begin{array}{l}\text { Personal Loyalty } \\
\text { (TT) }\end{array}$} & Loyalty is your inherent characteristic. & TT1 \\
\hline & You always appreciate loyalty. & TT2 \\
\hline & You want to be loyal with this company. & TT3 \\
\hline
\end{tabular}


values of the independent variables are known. In addition, independent-samples T-test, and One-way ANOVA are also used to examine the effects of investigated individual or organizational characteristics on the dependent variable in the regression model.

\section{Results}

Official survey was conducted in October 2019 for leaders: department heads/deputy heads, and team/production line managers. In addition, there are some participants who were introduced as talents by their leaders in textile and garment companies in Binh Duong. A total of 300 hard copies were sent out. There were 167 hard copies collected (55.67\%). After a screening process, 129 valid observations were used in this study.

\subsection{Descriptive Statistics of Surveyed Objects}

Among the 129 valid observations, Table 3 shows that the survey sample was eligible to represent the overall population.

Table 3: Descriptive statistics of surveyed objects

\begin{tabular}{|c|c|c|c|}
\hline \multicolumn{2}{|c|}{ Aspects } & \multirow{2}{*}{$\begin{array}{c}\text { Quantity } \\
68\end{array}$} & \multirow{2}{*}{$\frac{\text { Percentage (\%) }}{52.71}$} \\
\hline Gondor & Male & & \\
\hline है। & Female & 61 & 47.29 \\
\hline \multirow{4}{*}{ Age range } & $<30$ & 15 & 11.63 \\
\hline & $30-40$ & 41 & 31.78 \\
\hline & $40-50$ & 51 & 39.53 \\
\hline & $>=50$ & 22 & 17.06 \\
\hline \multirow{6}{*}{ Education } & $\leq$ High school & 6 & 4.65 \\
\hline & Intermediate & 10 & 7.75 \\
\hline & College & 19 & 14.73 \\
\hline & University & 71 & 55.04 \\
\hline & Master & 22 & 17.05 \\
\hline & Doctor & 1 & 0.78 \\
\hline \multirow{3}{*}{$\begin{array}{l}\text { Working } \\
\text { experience }\end{array}$} & $<5$ years & 15 & 11.63 \\
\hline & 5-10 years & 59 & 45.74 \\
\hline & $>=10$ years & 55 & 42.63 \\
\hline \multirow{2}{*}{ Ownership } & Private & 52 & 40.31 \\
\hline & FDI & 77 & 59.69 \\
\hline \multirow{4}{*}{ Firm size } & $<=300$ & 12 & 9.30 \\
\hline & $301-500$ & 29 & 22.48 \\
\hline & $501-1000$ & 35 & 27.13 \\
\hline & $>=1001$ & 53 & 41.09 \\
\hline
\end{tabular}

\subsection{Exploratory Factor Analysis}

The investigated scales were first analysed for their reliability by Cronbach's Alpha coefficient. Table 4 shows that the Cronbach's Alpha values of all eight components are greater than 0.6; thus, they are reliable for further analysis. In addition, the obtained results from EFA showed that all eight factors were extracted at an eigenvalue of 1.418 and the cumulative rotation sums of squared loadings of $69.82 \%$. These indicate that the EFA approach is appropriate in this study. Moreover, KMO of 0.763 and the Bartlett's test sig = 0.000 further confirm the appropriateness of the EFA method used in this study.

\subsection{Results of Linear Regression Analysis}

With the 129 valid observations, the average value of "talent retention" (KNDT) in the textiles and garment companies in Binh Duong was 3.207 on a scale of 5. Thus, talent retention is a noteworthy problem to be carefully considered for proper actions. What factors have affected such retention? What is the importance of each factor? To answer these questions, the multivariate linear regression analysis is used in this study. It is expressed as:

$$
K N D T=f\left(\begin{array}{l}
L C, B C, D T, C N, C T, D N, \\
M T, T T, G E N D, A G E, \\
A C A, E X P E, O W N, S I Z E
\end{array}\right)
$$

where: KNDT: Ability to retain talents; LC: Salary \& benefits; BC: Nature of work; DT: Training and promotion opportunities; CN: Recognition by organization; CT: Relationship with superiors; DN: Relationship with colleagues; MT: Working environment; TT: Personal loyalty; GEND- Gender; AGE- Age; ACA- Academic level; EXPEWorking experience (in years); OWN- Type of ownership; and SIZE- Firm size.

The results from regression model show that $\mathrm{LC}, \mathrm{BC}$, DT, CN, CT, DN, MT, TT, EXPE and OWN were found statistically significant as presented in Table 5 which shows that the independent variables are statistically significant, meaning that they have significant impacts on the talent retention of textile and garment companies in Binh Duong. Table 6 shows the importance of each factor affecting the talent retention ranked in descending order on the scale of 5 .

Thus, among the examined factors, both "working environment" and "personal loyalty" was rated more than 4 in the 5-point scale, indicating that every person surveyed is quite happy with the current working conditions provided by the companies, sees the concept of loyalty as an inherent virtue, seeks to foster loyalty, and want to be loyal to its present organization. Meanwhile, three other factors are below 
Table 4: Exploratory Factor Analysis and Scale Reliability Analysis

\begin{tabular}{|c|c|c|c|c|c|c|c|c|c|c|}
\hline \multicolumn{2}{|l|}{ Factors } & \multicolumn{8}{|c|}{ Component } & \multirow[t]{2}{*}{$\alpha$} \\
\hline & & \multirow{2}{*}{$\begin{array}{c}1 \\
0.87 \\
\end{array}$} & \multirow[t]{2}{*}{2} & \multirow[t]{2}{*}{3} & \multirow[t]{2}{*}{4} & \multirow[t]{2}{*}{5} & \multirow[t]{2}{*}{6} & \multirow[t]{2}{*}{7} & \multirow[t]{2}{*}{8} & \\
\hline \multirow{7}{*}{$\begin{array}{l}\text { Salary and } \\
\text { Benefits }\end{array}$} & LC6 & & & & & & & & & \multirow[t]{7}{*}{0.828} \\
\hline & LC3 & 0.84 & & & & & & & & \\
\hline & LC4 & 0.83 & & & & & & & & \\
\hline & LC2 & 0.83 & & & & & & & & \\
\hline & LC7 & 0.82 & & & & & & & & \\
\hline & LC5 & 0.72 & & & & & & & & \\
\hline & LC1 & 0.67 & & & & & & & & \\
\hline \multirow{6}{*}{$\begin{array}{l}\text { Working } \\
\text { Environment }\end{array}$} & MT1 & & 0.85 & & & & & & & \multirow[t]{6}{*}{0.831} \\
\hline & MT6 & & 0.82 & & & & & & & \\
\hline & MT3 & & 0.74 & & & & & & & \\
\hline & MT4 & & 0.71 & & & & & & & \\
\hline & MT2 & & 0.70 & & & & & & & \\
\hline & MT5 & & 0.65 & & & & & & & \\
\hline \multirow{5}{*}{$\begin{array}{l}\text { Relationship with } \\
\text { Colleagues }\end{array}$} & DN3 & & & 0.79 & & & & & & \multirow[t]{5}{*}{0.863} \\
\hline & DN5 & & & 0.79 & & & & & & \\
\hline & DN1 & & & 0.76 & & & & & & \\
\hline & DN2 & & & 0.70 & & & & & & \\
\hline & DN4 & & & 0.68 & & & & & & \\
\hline \multirow{5}{*}{$\begin{array}{l}\text { Recognition by } \\
\text { Organization }\end{array}$} & CN5 & & & & 0.82 & & & & & \multirow[t]{5}{*}{0.807} \\
\hline & CN3 & & & & 0.81 & & & & & \\
\hline & CN4 & & & & 0.77 & & & & & \\
\hline & CN1 & & & & 0.72 & & & & & \\
\hline & $\mathrm{CN} 2$ & & & & 0.65 & & & & & \\
\hline \multirow{4}{*}{$\begin{array}{l}\text { Relationship with } \\
\text { Superiors }\end{array}$} & CT2 & & & & & 0.82 & & & & \multirow[t]{4}{*}{0.842} \\
\hline & СT3 & & & & & 0.80 & & & & \\
\hline & CT1 & & & & & 0.71 & & & & \\
\hline & CT4 & & & & & 0.59 & & & & \\
\hline \multirow{4}{*}{$\begin{array}{l}\text { Training and } \\
\text { Promotion } \\
\text { Opportunities }\end{array}$} & DT3 & & & & & & 0.84 & & & \multirow[t]{4}{*}{0.839} \\
\hline & DT4 & & & & & & 0.82 & & & \\
\hline & DT2 & & & & & & 0.68 & & & \\
\hline & DT1 & & & & & & 0.64 & & & \\
\hline \multirow[t]{4}{*}{ Nature of Work } & $\mathrm{BC} 4$ & & & & & & & 0.77 & & 0.786 \\
\hline & $\mathrm{BC} 1$ & & & & & & & 0.75 & & \\
\hline & $\mathrm{BC} 2$ & & & & & & & 0.75 & & \\
\hline & $\mathrm{BC} 3$ & & & & & & & 0.69 & & \\
\hline Personal Loyalty & TT2 & & & & & & & & 0.77 & 0.815 \\
\hline & TT1 & & & & & & & & 0.74 & \\
\hline & TT3 & & & & & & & & 0.72 & \\
\hline
\end{tabular}


Table 5: Regression coefficients

\begin{tabular}{|c|c|c|c|c|c|}
\hline \multirow{2}{*}{ Variable } & \multicolumn{2}{|c|}{ Un-standardised Coefficients } & \multirow{2}{*}{$\frac{\text { Std. Coefficients }}{\text { Beta }}$} & \multirow{2}{*}{ Sig. } & \multirow{2}{*}{$\begin{array}{l}\text { Variance Inflation } \\
\text { Factor (VIF) }\end{array}$} \\
\hline & B & Standard Deviation & & & \\
\hline Cons. & 0.019 & 0.002 & & 0.000 & \\
\hline LC & 0.809 & 0.008 & 0.493 & 0.000 & 1.396 \\
\hline $\mathrm{BC}$ & 0.655 & 0.012 & 0.360 & 0.000 & 1.127 \\
\hline DT & 0.851 & 0.015 & 0.498 & 0.000 & 1.739 \\
\hline $\mathrm{CN}$ & 0.622 & 0.009 & 0.342 & 0.000 & 1.263 \\
\hline CT & 0.485 & 0.005 & 0.257 & 0.000 & 1.031 \\
\hline DN & 0.713 & 0.006 & 0.389 & 0.000 & 1.224 \\
\hline MT & 0.763 & 0.027 & 0.517 & 0.000 & 1.037 \\
\hline TT & 0.806 & 0.004 & 0.457 & 0.000 & 1.553 \\
\hline EXPE & 0.359 & 0.005 & 0.251 & 0.000 & 1.219 \\
\hline OWN & 0.455 & 0.009 & 0.330 & 0.000 & 1.214 \\
\hline
\end{tabular}

Table 6: Importance level and Evaluation

\begin{tabular}{|l|l|c|c|}
\hline \multicolumn{1}{|c|}{ Importance } & \multicolumn{1}{|c|}{ Factor } & Std. Regression Coefficients & Evaluation \\
\hline 1-MT & Working environment & 0.517 & 4.168 \\
\hline 2-DT & Training and promotion opportunities & 0.498 & 2.883 \\
\hline 3-LC & Salary and benefits & 0.493 & 2.769 \\
\hline 4-TT & Personal loyalty & 0.457 & 4.627 \\
\hline 5-DN & Relationships with colleagues & 0.389 & 2.904 \\
\hline 6-BC & Nature of work & 0.360 & 3.657 \\
\hline 7-CN & Recognition by organization & 0.342 & 3.286 \\
\hline 8-OWN & Ownership & 0.330 & - \\
\hline 9-CT & Relationship with superiors & 0.257 & 3.107 \\
\hline 10-EXPE & Experience & 0.251 & - \\
\hline
\end{tabular}

average ( 3 points) and these three factors are quite important to the ability to retain talent. This is probably the reason that the average value of KNDT in this study is only 3.207.

To investigate the cause of this phenomenon, t-test and one-way ANOVA tests for the equality of mean values of KNDT by the criteria of personal and organizational characteristics were conducted. The results show that there are significant differences in the KND of talent between foreign companies (4.18/5.00) and private companies (2.44/ 5.00 ), and between those with more than 15 years of working experience (3.86/5.00) and those less than five years of experience $(3.37 / 5.00)$. Other features have insignificant impact on talent retention.

\section{Discussions and Conclusion}

The above results show that organizations need to pay attention to all the relevant factors in order to improve their talent retention; for example, they need to create a conductive working environment by supplying them with the tools and equipment they need to get things done in an optimal, efficient and effective manner; or they also need to provide creative space so they always feel excited with their work. In addition, they need to recognize the contributions by their employees to encourage their dedication. Based on the factors found, the following suggestions are made regarding the three most important ones.

Personal loyalty: Loyalty is formed from the education of the family, school and society. Therefore, in order to be able to recruit employees with the true loyalty, the recruitment process should be more focused. Specifically, after the candidates undergo interviews and tests, the recruiting team can challenge the "brightest" candidates to handle a situation which puts the candidate on the insider's position to solve a problem of "either quit or continue" or 
explain why the character in that situation behaves like that (of course, the situation should relate to the concept of loyalty of these candidates). After they are employed, the recruiter can observe their practical circumstances to see if their behavior is consistent with their original concept and judge whether the person is loyal before assigning them to important positions in the organization.

Training and promotion: Every employee desires the opportunity to improve themselves and develop in the right environment. Therefore, if their basic needs are met, the organization can easily maintain the attachment of their workers, including talents because they feel respected in the organization and having the opportunity to improve their knowledge, skills and ability to contribute to the growth of the organization. Concurrently, if the organization offers their employees the opportunity to take part in training courses, they should be also oriented about the possible promotion; otherwise the trainings fail to have practical sense because the effort of a person generally aims at getting promoted and gaining a suitable job position in the organization. Therefore, when the promotion policy is reasonable, the organization can easily improve productivity and operational efficiency. In addition, it helps organizations select right people to be their successors or lead/guide an important organizational strategy.

Relationship with colleagues: Many private businesses employ their relatives and assign them to take many managing roles though they are unqualified for such positions. They mostly depend on relationships with the leaders; thus, they are rarely friendly with people around them. As they are usually "granted with privileges" by the leaders, such "unfair" environment significantly affects the working psychology of other people; especially, talented people find it unacceptable to work in an organization with people like these. Consequently, many private businesses are unlikely to retain their talents long in their businesses.

One of the easiest activities with which to build a good relationship among the employees is to regularly organize networking events for people in the same department and among departments so that they have more time to understand each other better, build stronger solidarity and foster a "helping and sharing" culture. In particular, businesses should have some activities that require group collaboration. In addition, organization needs to "handle" individuals who are not competent, but often envy the performance of talents and the benefits offered to them. Because these individuals not only fail to help the talents in the organization, but also become the "obstacles" distracting and reducing the enthusiasm of talents as well as creating bad psychology and unstable emotion for talents. As a result, in the long run, it is difficult for organization to retain their talents.

In short, over the past few years, the phenomenon of "leap frog" in the textile and garment industry of Binh Duong province is quite complex. How to retain talents is always the top concern of the textile and garment companies. In order to have effective solutions to improve the talent retention, this study explores the impacting factors; specifically, through the survey of 129 participants considered as talents in the companies, it is found that talent retention in these companies is influenced by the following factors: (1) working environment; (2) training and promotion opportunities; (3) salary and benefits; (4) personal loyalty; (5) relationship with colleagues; (6) nature of work; (7) organizational recognition; (8) type of ownership; (9) relationship with superiors; and (10) working experience.

From these findings, a number of management implications for textile and garment firms to improve their retention were proposed to serve their sustainable development. In addition, this study also found that foreign firms have better ability in retaining their talents than private ones for various reasons. Consequently, private domestic firms need to work harder to avoid a "brain drain" of their talents leaving for foreign firms.

\section{References}

Axelrod, B., Handfield-Jones H., \& Michaels E. (2002). A new game plan for C players. Harvard Business Review, 80(1), 8090.

Bartel, A. P. (2004). Human Resource Management and Organizational Performance: Evidence from Retail Banking. Industrial \& Labor Relations Review, 57, 181-203.

Becker, B. E., \& Huselid, M. A. (2006). Strategic human resource management: Where do we go from here? Journal of Management, 32, 898-925.

Benjamin, B., \& Dunford, W. R. (2010). When do high level Managers believe they can influence the stock price? Antecedents of stock price expectancy conditions. Human Resource Management, 49(1), 23-43.

Birt, M., Wallis, T., \& Winternitz, G. (2004). Talent retention in a changing workplace: An investigation of variables considered important to South African talent. South African Journal of Business Management, 35(2), 25-31.

Botha, M. B. (2011). An employer brand predictive model for talent attraction and retention. South African Journal of Human Resource Management, 9(1), 1-12.

Chowdhury, M. S. (2007). Enhancing Motivation and Work Performance of the Salespeople: The Impact of Supervisors' Behavior. African Journal of Business Management, 1(9), 238243.

Chulanova, Z. K., Satybaldin, A. A., \& Koshanov, A. K. (2019). Methodology for Assessing the State of Human Capital in the Context of Innovative Development of the Economy: A Three-Level Approach. Journal of Asian Finance, Economics and Business, 6(1), 321-328. http://doi.org/10.13106/jafeb.2019.vol6.no1.321 
Chulanova, Z., \& Ussenova, A. (2015). Human Capital and Methodic of Determination of Its Cost: A Case of Kazakhstan. Journal of Asian Finance, Economics and Business, 2(2), 1925. https://doi.org/10.13106/jafeb.2015.vol2.no2.19.

Gagné, F. (2000). Understanding the complex choreography of talent development through DMGT-Based analysis. Oxford: Elsevier

Guillon, O., \& Cezanne, C. (2014). Employee loyalty and organizational performance: A critical survey. Journal of Organizational Change Management, 27(5), 839-850.

Hair, J. F., Black, W. C., Babin, B. J., Anderson, R. E., \& Tatham, R. L. (2010). Multivariate data analysis. Upper Saddle River, NJ: Prentice - Hall.

Hassan, M., Hassan, S., Khan, K. U. D., \& Naseem, M. A. (2011). Employee retention as a challenge in leather industry. Global Journal of Human Social Science, 11(2), 8-13.

Hossain, M. K., \& Hossain, A. (2012). Factors Affecting Employee's Motivation in Fast Food Industry: The Case of KFC UK LTD. Research Journals of Economics, Business and ITC, 5, 22-29.

Ibrahim, M., \& Al Falasi, S. (2014). Employee loyalty and engagement in UAE public sector. Employee Relations, 36(5), $562-582$.

Iqbal, A., Tufail, M. S., \& Lodhi, R. N. (2015). Employee loyalty and organizational commitment in Pakistani organizations. Global Journal of Human Resource Management, 3(1), 1-11.

Lathitha, C. (2012). Managing employee attrition- The HR role and challenge. International Journal of Research in Management, Economics and Commerce, 2(2), 262-267.

Logan, J. K. (2000). Retention tangibles and intangibles: More meaning in work is essential, but good chair-massages won't hurt. Training \& Development, 54(4), 48-50.

Martensen, A., \& Grønholdt, L. (2015). Internal marketing: A study of employee loyalty, its determinants and consequences. Innovative Marketing, 12(1), 92-116.

Masibigiri, V., \& Nienaber, H. (2011). Factors affecting the retention of Generation $\mathrm{X}$ public servants: An exploratory study. SA Journal of Human Resource, 9(1), 1-11.

Matkeri, P. N. (2011). Talent Retention: Ordinary people extra ordinary creation: A true story of Askshardham Temple Delhi. International Journal of Research in Finance \& Marketing, 1(2), 102-117.

Menefee, J. A., \& Murphy, R. O. (2004). Rewarding and retaining the best: Compensation strategies for top performers. Benefits Quarterly, 20(3), 13-20.

Michaels, E., Jones, H. H., \& Axelrod, B. (2001). The war for talent. Boston, MA: Harvard Business School Press.

Mohammed, A. (2015). The impact of talent management on employee engagement, retention and value addition in achieving organizational performance. International Journal of Core Engineering \& Management, 1(12), 142-152.
Moorhead, G., \& Griffin, R. W. (2004). Organizational Behavior: Managing People and Organizations. Pennsylvania State University: Houghton Mifflin.

Ng'ethe, J. M., Iravo, M. E., \& Namusonge, G. S. (2012). Determinants of academic staff retention in public universities in Kenya: Empirical review. International Journal of Humanities and Social Sciences, 2, 205-212.

Nguyen, T. L., Tai, D. H., Quynh, D. M., \& Giang, P. X. (2019). Macro factors affecting human resource quality in Dong Nai industrial parks. International Journal of Advanced and Applied Sciences, 6(7), 1-9.

Nunnally, J. C., \& Bernstein, I. H. (1994). Psychometric theory (3rd Ed.). New York: McGraw-Hill.

Peterson, R. A. (1994). A meta-analysis of Cronbach's coefficient alpha. Journal of Consumer Research, 2(2), 381-391.

Quynh, D. M., Tai, D. H., Nguyen, T. L., \& Son, P. N. (2017). Determinants of Human Resource Quality in Dong Nai Province, Vietnam. International Journal of Scientific Study, 5(6), 207-215

Reena, F. E., Jalilvand, M.R., Sharif, M., \& Khanzadeh S. A. (2009). A study of influential factors on employees' motivation for participating in the in-service training courses based on modified expectancy theory. International Business Management, 2(1), 157-169.

Rola, C. M., \& Thomas, G. (2013). Talent and leadership development practices as drivers of intention to stay in Lebanese organisations: The mediating role of affective commitment. The International Journal of Human Resource Management, 24(21), 4046-4062.

Safiullah, A. B. (2015). Employee motivation and its most influential factors: A study on the telecommunication industry in Bangladesh. World Journal of Social Sciences, 5(1), 79-92.

Schuler, R. S., Jackson, S. E., \& Tarique, I. (2011). Global talent management and global talent challenges: Strategic opportunities for IHRM. Journal of World Business, 46(4), 506-516.

Scullion, H., Collings, D. G., \& Caligiuri, P. (2011). Global talent management. Journal of World Business, 45(3), 105-108.

Singh, S., \& Dixit, P. K. (2011). Employee retention: The art of keeping the people who keep you in business. VSRD International Journal of Business \& Management Research, 1(7), 441-448.

Slater, S. F. (1995). Issues in conducting marketing strategy research. Journal of Strategic Marketing, 3, 257-270.

Slavich, J. A. (2011). Talent management: The key to economic recovery. South Carolina Business, 32(3), 24.

Tansley, C. (2011). What do we mean by the term "talent" in talent management? Industrial and Commercial Training, 43(5), 266274.

Tarique, I., \& Schuler, R. S. (2010). Global talent management: Literature review, interactive framework and suggestions for further studies. Journal of World Business, 3, 122-133. 
Thorne, K., \& Pellant, A. (2007). The essential guide to managing talent: How top companies recruit. London: Kogan Page Publishers.

Tulsi, P., \& Ji, Y. (2020). A Conceptual Approach to Green Human Resource Management and Corporate Environmental Responsibility in the Hospitality Industry. Journal of Asian Finance, Economics and Business, 7(1), 195-203. https://doi. org/10.13106/jafeb.2020.vol7.no1.195
Williams, M. (2000). The war for talent: Getting the best from the best. London: Chartered Institute of Personnel and Development (CIPD).

Yen, H. J., Hu, P. J. H., Hsu, S. H. Y., \& Li, E. Y. (2016). A multilevel approach to examine employees' loyal use of ERP systems in organizations. Journal of Management Information Systems, $33(2), 1-32$. 